\title{
Training the animator anew: Developing cross-disciplinary opportunities for puppetry in arts, health and education ${ }^{1}$
}

ROSS W. PRIOR, University of Wolverhampton

\begin{abstract}
:
This positioning article explores a reimagining within the field of applied theatre where through the medium of puppetry, the art and artist may become one as a way of healing. Building upon conceptual principles of animism, transference and embodiment, it is proposed that puppeteer training be usefully integrated into higher education applied arts and health programmes as an extension to existing programmes. Value is given to the metaphorical use of the puppet in both education and therapy. It is proposed that puppeteers may gain value from engaging with crossdisciplinary art-based research as a way to further understand puppetry's uses and furthering their own practices.
\end{abstract}

Keywords: puppetry, animism, transference, embodiment, applied arts, health, artbased research, training

\section{Introduction: A personal story with Pelham Puppets}

Puppetry has been much a part of my life for as long as I can remember. As a child the act of bringing an inanimate object to life was a wonder and a joy. I remember an occasion when I was home ill from Kindergarten and I entertained myself for some time with an imaginary 'friend'. This friend was conjured simply by a reflection of sunlight made from a small hand-held mirror. I made the image flicker and dance around the room. The simplicity!

I later graduated from the mirror to a discovery of Pelham Puppets - undoubtedly one of the greatest joys to enter my life. In fact, before continuing, the Pelham story is significant to note here as something of an English institution. Pelham Puppets was a company founded by Bob Pelham in Marlborough, Wiltshire, England in 1947 (its

\footnotetext{
1 First presented by the author as a keynote address at Broken Puppet 3 International Symposium on 'Puppetry: Community Health, Wellbeing and Disability: Professional Training Opportunities', 18 April 2019.
} 
name was originally Wonky Toys Ltd). It arguably produced the finest range of commercial puppets ever seen. The 1950s was a prolific period for the company but it suffered a setback in 1961 with a factory fire with the lost of 10,000 puppets and many valuable moulds. The business was resurrected and in 1963 over 226,200 puppets were produced making it a record year for the number of puppets made and included a whole new range. The upward trend continued into the 1970s with about 100,000 puppets finding their way each year to the United States alone. By 1977, with the company's workforce approaching two hundred employees and nearly one hundred home workers, Pelham Puppets had become the largest single employer in the town of Marlborough. Bob Pelham died in 1980 and his wife Ann took over the business until its end in 1986. In 2008 David Leech, a former employee, took over the business name and produced a new line inspired by some of the former range. It is therefore clear that Pelham Puppets directly touched the lives of more than several million children across the world.

Purchasing Pelham Puppets and performing with them became a major hobby for me. By the age of twelve I had amassed a fledgling collection, however just before Christmas that year I lost my puppets when my family's home burnt to the ground. I had lost my 'friends'. However, in due course I began to re-establish my collection and this time it grew exponentially and continues to this very day! I now own a vast collection of Pelham Puppets representing fine examples across the decades.

As an only child, puppets gave me companionship, and as a shy child, puppets offered me a comfortable way of expression and artistic engagement. Undoubtedly there was some delight in being in control but also the puppetry form offered me a way of telling stories and entertaining others. The availability of Pelham Puppets made my engagement with the form enticing and readily accessible. The company also facilitated the Pelpup Club, which so many of us around the world joined. Bob Pelham encouraged children to work together for the mutual enjoyment of puppetry. We received a certificate, a badge and a magazine twice per year. The club provided a community of practice where we shared scripts, ideas, set designs and could advertise for pen pals worldwide. Like so many others around the world, Pelham Puppets gave me a place to belong. 
With this personal background outlining the power of the form, I will begin to unpack the relevance of applied puppetry more broadly to the area of health and wellbeing and argue for its inclusion in applied theatre and art therapy education programmes.

\section{The art of puppetry as medicine}

In his book Art as Medicine, Shaun McNiff (1992) explores a range of techniques whereby art is used in therapy to improve health. This particular relationship that art can have to personal healing shifts perception that art is simply decorative or an artist's expression alone. Whilst the beauty of a finely crafted puppet can be appreciated, it is not until someone brings the puppet to life that it can be fully appreciated.

Rather than assuming art is simply static, repositioning 'art as a process, in which understanding is constructed and co-constructed with others' (Prior 2018: 11) is the dynamic at play. Puppetry, like all art, is a particular act of expressing feelings, thoughts and observations. Therefore, the learning potential in puppetry, as in all art, is 'powerful as it leads us to the deepest places of human feeling, provides enlightenment and raises the human spirit' (Prior 2017: 266) and as such, art has become recognized widely as a process of therapy and healing (Clift et al 2009; McNiff 1992, 2009, 2019; Prior 2010, 2017).

Similarly the beneficial applications of what I term 'puppetry as medicine' are vast and yet currently largely under-explored. The first and only article to appear in the Journal of Applied Arts and Health relating to puppetry before 2020 was by Melissa Trimingham in 2010 and was within the context of neurodiversity and autism in particular. In fact much of the limited extant literature is found mainly in journals of education or psychology. Trimingham (2010) at the time noted that 'there is very little written on puppets. Even less has been written on the use of puppets in therapy with children' (p. 252). Ackland Tilbrook et al (2016), in a review of relevant literature on puppetry, agree that 'a paucity of empirical evidence of the use of puppetry by healthcare exists despite multiple recommendations that it is a successful technique' (p. 77). However they confidently conclude that 'evidence to date suggests that puppetry is a useful and popular technique used by play therapists and health professionals in a variety of contexts' (p. 77). Likewise, Persephone Sextou (2016) in 
a project centred on Theatre for Children in Hospital (TCH) uses mixed artforms, including puppetry 'to inspire young audiences in hospital and normalize their stay' (p. 42).

One of the unique qualities of puppetry is the ability to synthesise a range of artforms, which can combine as part of the 'sacred' experience. McNiff (2019) states: 'When art and artists are approached as engaging all of expression and not just visual forms, commonalities are likely to expand to enactment, rhythm, ritual, and a sense of sacred presence' (p. 163). Therapeutic uses of art have regained popularity in recent years and it seems quite logical that puppetry takes a place. The relationship between art and healing is encapsulated by McNiff (2019) as the direct, unmediated response to an artistic expression and its impact on us. He asserts: 'I am more committed than ever because I dependably experience art healing in my own painting together with what I see in my work with others' (p. 164).

\section{Artistic ways of knowing}

'Artists call upon multiple ways of knowing, which are likely to become further enhanced through the experience of practice' (Prior 2013: 162). These complex understandings are entwined within the act of doing and being, and because they can be so embodied, the outsider may significantly underestimate all that is involved with being an artist and in particular here, a puppeteer. Therefore, within this complexity, it ought to be firmly acknowledged that 'knowledge is less a discovery than it is a construction' (Eisner 2002: 211). Knowledge acquisition is not linear but is gained more as a web of understanding over time and frequently more randomly than one might assume.

As far as we are concerned here with puppetry, knowledge is constructed in and through artistic practice. This situation contrasts with traditional scientific experimentation, although one could argue that in actuality, science too shares a broader knowledge base that is constructed in and through its own practice. There has been an awakening of understanding leading to an acceptance of embodied knowledge, situated knowledge and enacted knowledge which offer artist-researchers more useful insights than might be gained through scientific experimentation or 
through the social sciences. Detachment, objectivity, controlled experimentation, random trials and rationality do not reach the heart of the distinctiveness of artistic inquiry. 'Artistic practice and experimentation tend to place the artist firmly in the middle, and every situation is entirely unique' (Prior 2018: 7).

Puppetry, like all art, is a particular act of expressing feelings, thoughts and observations. Therefore, the learning potential as in all art is 'powerful as it leads us to the deepest places of human feeling, provides enlightenment and raises the human spirit' (Prior 2017: 266). What is particular to puppetry is evidenced in its unique nature, which can be framed as 'animism', 'transference and embodiment' outlined below.

\section{Animism}

In the 1980s I was fortunate to be chosen to train with master puppeteer Philippe Genty. He had an eclectic background, originally training as a graphic designer and began his career with a trip during which he discovered puppetry throughout the world. His film with co-director Yves Brunier, Le Tour du Monde des Marionettes (Puppets Around the World 1969), documented the art of puppetry around much of the world. A creator of different manipulation techniques, Philippe Genty established his own company in 1968. In the mid 1970s he also became famous with a television series, Gertrude et Barnabé (Gertrude and Barnabas). His work was at first influenced by the cabaret form, but he soon began to explore the use of Black Art theatre whereby through the controlled use of side beam lighting, the puppeteer gives the illusion that manipulated objects have a life of their own, without a visible means of operation.

Starting from 1980, his regular creations for the Théâtre de la Ville (Paris) followed by highly successful world tours brought a new dimension to his artistic production. The movements of materials and forms created fantastical illusions during performances in which theatrical elements had astonishing flexibility where puppetry truly met illusion. The puppet as 'object' progressively expanded into a scenic object for which Genty collaborated with his wife Mary Underwood, an accomplished choreographer. Philippe Genty once said to me that he no longer employs puppeteers 
but preferred to cast dancers in the role as they have a stronger understanding of the art of movement and kinaesthetics, which was more important to his style of work.

In his latter work, Philippe Genty became interested in the non-verbal, rarely using text in his productions (Zigmund Follies, a recreation in 2000 of the Sigmund Follies of 1983), exploring journeys into individual psychoses and the subconscious. These themes can again be found at the heart of Lignes de fuite (Vanishing Points 2001), where the 'puppet' language is based on a manipulation of space and its perception, as well as on anthropomorphic figures (doubling and mirror games), in a theatre of imagery and illusion.

Philippe Genty's philosophy of animism was based upon understanding how an inanimate object might move by itself, if it could. For example a brush would use its own bristles to move along the floor rather than being jumped along staccato fashion. Animism literally means the breath, spirit and life-force that can be found in objects and nature - as animated and alive. This notion connects with notions of shamanism found in some forms of art therapy. McNiff (1979) draws the parallel between the shaman and the art therapist:

The earliest manifestation of what we now call the "therapist" was the shaman who has been known as a "medicine man," one who works with the supernatural, a technician of the sacred, a master of ecstasy, mystic, healer, priest and artist. In essence, the work of the shaman involves all of these things.

Incidentally, there are further parallels between Genty and McNiff as both are deeply influenced by Carl Jung (1977) who advanced the idea of depth psychology and the power of the unconscious, particularly through dreams and to engage art in therapy. In terms of animism, it is the spiritual essence of the object that one seeks to find and explore. The puppeteer is akin to a shaman in finding a truth in the object, situation and the moment.

\section{Transference and embodiment}

'Transference' was first described by Sigmund Freud ([1901] 2010) the founder of psychoanalysis. He considered transference to be an important part of psychoanalytic treatment. A modern, social-cognitive perspective on transference explains how it can 
occur in everyday life. For example, when people meet a new person who reminds them of someone else, they unconsciously infer that the new person has traits similar to the person previously known to them. This perspective has generated a wealth of discussion that illuminates how people tend to repeat relationship patterns from the past in the present.

There are a few conflicting ideas about transference, mostly to do with psychology's mixed use of terminology. Depending upon to whom you refer, 'transference' could take on several meanings. However the classic use of the term 'transference' includes the redirection of feelings and desires, especially of those unconsciously retained or embodied from previous experience or even from childhood towards a new person or object. We all do this most of the time.

There is, however, great potential in exploring how transference occurs when using puppets and offers therapists and applied arts workers a rich opportunity. Like conventionally tested drama-in-education or applied theatre practice, the puppet becomes the metaphor or the personification of the 'other'. This deflects the immediate exposure of the individual and increases the opportunity to explore issues more openly and somewhat more safely. Tilbrook et al (2017) suggest:

Puppets are a pathway to provide children with a voice, more so when the child is the operator and they can use the puppet as a tool to act out personal fears and anxieties. Despite who the operator of the puppet is, child, therapist or nurse, this interaction helps to identify the child's preferences for care and provides a valuable insight into the child and their individual needs. Communication between the child and the operator of the puppet is facilitated by puppetry and this appears to have flow on effects on developing and facilitating the adultchild relationship. (pp. 77-78)

Transference in therapy might be very helpful in pointing the direction of unhealed wounds. In applied art working more generally, transference offers a distancing device, which may create an environment more conducive to safely exploring personal issues of the participants, and puppets can assist in doing this. It is the spontaneous immediacy of transference that is of benefit (Freud ([1901] 2010) rather than a thought-through account. Client use of puppets in therapy or students within an 
educational setting would likely exhibit a degree of transference. 'A puppet is an object, a physical entity, but, crucially, imbued with "mindful attributes" (Trimingham 2010: 262) which makes it a powerful and effective vehicle for transference.

\section{Puppetry as a process of co-participation}

Education is changing over time in how the learning experience is constructed. Learning is now seen as a way of being in the social world, not simply as a way of coming to know about it (Lave and Wenger 1991). 'A challenging notion to emerge in more recent years relates to the changing relationship between professional and student' (Prior 2012: 208). The notion of co-participation in learning, with students learning alongside practitioners and other students, acknowledges the collaborative and ongoing nature of learning and of knowledge construction itself:

This thinking seems to have come about through a growing mistrust of absolute professional authority, the acknowledgment that co-participation may result in more being known than one line of thinking alone, and that individuals must learn for themselves. Indeed the ownership of knowledge is nurtured organically rather than merely being imparted from an external 'authority'. (Prior 2012: 208)

It is true that traditionally artists of all types learnt from the 'acknowledged masters', which undoubtedly consisted of some imitation and direct instruction alongside the apprentice's own essential experimentation of the form. I identify this in my own learning from Philippe Genty. However, knowledge is generated through the tireless practising and refining of one's craft. Some areas of academia may find the direct skill-based training approach confronting, seeing it as not 'academic' enough. More traditional past academic approaches perpetuate the model that authority is largely derived from the possession of declarative knowledge with the belief that it is turned into procedural knowledge. However, subsequent artistic research (McNiff 2013, 2019; Prior 2013, 1918) has successfully demonstrated that there is much to be learnt in and through the artistic process itself - to the artist, this is generally self-evident.

Even between various art forms we see a considerable collaborative working to achieve the art itself. Music and the performing arts such as drama and dance know 
the primacy of working together to produce a unified effect. Whilst individuals play their own part, there is a collective will that governs the artistic process. But how might we see a range of art forms co-participating, not only amongst themselves, but working with communities more generally? Jean Rumbold et al (2013) put forward the view that 'using collaborative and cooperative forms of art-based inquiry can translate what may start as very personal quests into projects with practical social relevance' (p. 66). Rather than assuming that collaborative learning waters down the experience, there is rich interconnectivity at work that enhances the learning experience and can have positive social implications. McNiff in his work also addresses the potential of collaboration:

Everything is shaped from something else and in cooperation with agencies other than ourselves. Life is always created from interplay among different participants who make contact, influence one another, exchange their essential natures, merge, and generate new forms. (McNiff 2003: 2)

McNiff additionally suggests that 'if creative expression is to enlarge its place in our communities, there has to be a clear value attached to it [...] and benefits of creativity in group[s]' (2003: 25). This is where the idea of art is moved into the realm of communal or collective working, promoting benefits for community as well as new ways to research the collective impulse (p. 55).

\section{Art-based research in puppetry}

It is self-evident that within the collaborative act there is tremendous potential for artbased research to be undertaken, moving away from the idea of the lone researcher or lone artist. This type of research offers great benefit to developing understandings of processes when two or more artists come together and further engage within the community. It is through art-based research and through understandings of embodied knowledge(s) that allows for deep understanding leading to greater personal facility and expertise. I have previously offered the following definition of art-based research:

Art as research involves a diverse range of human activities in creating visual, auditory or performed artworks, expressing the artist's imaginative and/or technical skill, intended to be appreciated for their beauty or emotional impact. Art as research uses systematic investigation into the study of process, materials and sources in order to understand art more completely and reach new conclusions. The primary 
components in using art as research are documentation, discovery and interpretation for the purpose of the advancement of artistic knowledge and furthering understanding of all of life and other disciplines too. (Prior 2018: 3)

Unlike the wider field of performance, puppeteers have not been inclined to seen themselves as researchers, however their artistic practice is researchable and this is where an understanding of art-based research is useful. In contemplating the advocacy for artbased research McNiff (2013) suggests that the 'biggest opportunity and challenge facing art-based research today is getting the people with the most to gain from the discipline to believe in it, become involved, perfect the process and realize the advantages it offers' (p. $3)$.

Puppeteers may have traditionally tended to actively shy away from anything considered 'research' unless it involved puppet history, character or other dramaturgical research perhaps. Largely this situation appears to be perpetuated by those academic models of research that do not connect directly with artistic practice. However art-based research does not in anyway attempt to disrupt the organic nature of producing one's art but rather allows the artist/puppeteer to research processes at a time when it is appropriate to do so.

\section{Integrating puppetry training in applied theatre education}

Professional accreditation to work within the applied arts and health field is a matter for considerable contemplation. There is an obvious need for people to be adequately prepared to work with vulnerable groups within society, however it would not be desirable to create further blocks for puppeteers to navigate their work within communities - as long as it is informed and 'does no harm'. But how have applied theatre workers or applied puppeteers been prepared for the work they are to undertake? It is likely that many have undergraduate drama or theatre arts experience prior to a Masters programme in Applied Theatre. However it is problematic when these Masters programmes claim their role as 'intervention' and 'therapy'. How can we be confident that students are being adequately prepared in a limited number of modules offered in these programmes of study? Further, where is puppetry in the applied theatre curriculum?

There is reason to be concerned at the adequacy of preparing applied theatre students to engage with the wide-ranging disciplines of sociology, psychology, therapy, and public 
health (Prior 2016). Further, 'the language used in applied theatre programme descriptors run the risk of over simplification and do not provide immediately clear distinctions between applied theatre and therapy' (Prior 2016: 52). Applied puppetry as a field too, needs to be clear about the distinctions and how adequately puppeteers working in this area are prepared for their role.

Prendergast and Saxton (2009) raise further important and related questions in applied theatre more widely:

...how do we value what we do? By what criteria do we judge the effectiveness of the work? What are the implications of short-term results when laid against what traces remain years later? What claims can we make for "transformation" when the money has run out, the project is over and the facilitators have moved on? What is the language we are using to describe what we do and how is it helpful? (p. 188)

Prendergast and Saxton also believe there are considerable ethical considerations surrounding the use of applied theatre. Philip Taylor (2003) finds it useful to see that 'a central principal in applied theatre is its break with certainty, that rather than pushing a moral platitude or a statement of political correctness, the applied theatre practitioner is working toward ambiguous and incomplete moments' (p. 98).

In defining the role, Taylor (2003) uses the term 'teaching artist' to describe the applied theatre practitioner, bringing 'both the skills of presenting theatre work and the rare ability to act as educators who can help process the program's teaching points with diverse groups' (p. 53). Taylor goes on to state that:

In the applied theatre, the artists' teaching skills are just as important, if not more so, than theatrical presentation for it is in the teaching ability of the artists that the applied nature of the work will be realized. (p. 53-54, original emphasis)

Developing cross-disciplinary opportunities for puppetry in arts, health and education seems to present itself as a rich opportunity if approached with a thorough understanding of those opportunities and limitations. There is a distinct educational or teaching (pedagogical/andragogical) aspect of applied theatre practice. Therefore any 
higher education programme of this type might essentially need to contain thorough preparation for education and training along with the individual possessing the necessary personality to become an artist-educator (Prior 2016). No matter how you frame this work, distinctions between therapy and education should be made, and in the case of therapy it would be imperative that educational programmes demand particular personal qualities and informing pre-qualifications. There is certainly a role for puppeteers to engage in using puppetry as a vehicle for collaborative learning, exploration of 'self' and others and providing a safe form of transference to tackle a wide range of issues.

\section{Conclusion}

Seeing the art of puppetry as a process, in which understanding is constructed and coconstructed with others, is very much at the heart of using art as research and can evidence what we do in applied arts and health practice. Whilst artistic research differs from science and the social sciences, it is simply a mode of inquiry that best suits the form, as it is the form that is of empirical interest alongside the artistic process. Once this is fully understood within higher education, we may begin to see the dissolution of those unhealthy divides pitting artist versus researcher and practitioner versus teacher. Using art as research provides a natural educational cadence for those of us who do not see borders between artist, researcher and educator in and through the production of art. A convergence of roles allows for artist/puppeteer and academic to become one. Art as research seeks to reveal and understand that which is bound in aesthetic experience and is enacted and embodied both in and through artistic processes (Prior 2018: 11).

There is tremendous opportunity for puppeteers to be trained anew to undertake applied theatre and therapy work. Equally the art of puppetry could find a worthwhile place within existing applied theatre and therapy programmes. Developing notions of animism, transference and embodiment may provide the field with ways of further articulating possibilities within theory and practice. Applied puppetry is rich with potential and it is timely that the field develops further research and scholarship to understand that potential. To these ends art-based research offers the field particular capacity for development and its anticipated collective maturation. 


\section{References}

Clift, Stephen, Hancox, Grenville, Morrison, Ian, Hess, Bärbel, Kreutz, Gunter and Stewart, Don (2009), 'Choral singing and psychological wellbeing: Quantitative and qualitative findings from English choirs in a crossnational survey', Journal of Applied Arts and Health, 1: 1, pp. 19-34.

Eisner, Elliot W. (2002), The Arts and the Creation of Mind, New Haven: Yale University Press.

Freud, Sigmund ([1901] 2010), The Psychopathology of Everyday Life, USA: Pacific Publishing Company.

Genty, Philippe and Brunier, Yves (dirs) (1969), Le Tour du Monde des Marionettes, Paris: ORTF, UNIMA, UNESCO.

Genty, Philippe (dir.) (1971-1972), Gertrude et Barnabé, France: Philip Genty. (dir.) (2000-2003), Zigmund Follies, MCNN - Center of Creation and Production of Nevers / Compagnie Philippe Genty, touring. (dir.) (2003-2006) Lignes de fuite (Vanishing Points), Compagnie Philippe Genty, touring.

Irwin, Eleanor (1985), 'Puppets in Therapy: An Assessment Procedure', American Journal of Psychotherapy, 39: 3, pp. 389-400.

Jung, Carl G. (1977), The Symbolic Life: Miscellaneous Writings, Collected Works of C.G. Jung, Volume 18, Princeton, N. J.: Princeton University Press.

Lave, Jean and Wenger, Etienne (1991), Situated Learning, Cambridge: Cambridge University Press.

McNiff, Shaun (1979), 'From Shamanism to art therapy', Art Psychotherapy, 6, pp. 155-61, Oxford: Pergamon Press Ltd. (1992), Art as Medicine: Creating a therapy of the imagination. Boston: Shambhala. (2003), Creating with Others: The Practice of Imagination in Life, Art and the Workplace, Boston: Shambhala. (2009), Integrating The Arts In Therapy: History, Theory, And Practice, Springfield, Illinois: Charles C Thomas. (ed.) ( 2013 ), Art as Research: Opportunities and Challenges, Bristol: Intellect. 
(2019), 'Reflections on What "Art” Does in Art Therapy Practice and Research', Art Therapy: Journal of the American Art Therapy Association, 36: 3, pp. 162-165.

Prendergast, Monica \& Saxton, Juliana (eds) (2009), Applied theatre: International case studies and challenges for practice. Bristol: Intellect.

Prior, R. W. (2010), 'Editorial', Journal of Applied Arts and Health, 1: 1, pp. 3-6. (2012), Teaching Actors: Knowledge Transfer In Actor Training, Bristol: Intellect.

(2013), 'Knowing what is known: Accessing craft-based meanings in research by artists' in S. McNiff (ed.) (2013), Art as Research: Opportunities and Challenges, Bristol: Intellect, pp. 161-169.

(2016), From 'discovered' to 'constructivist' in applied theatre programmes: Preparing postgraduate students as future artist-educators, Arts Praxis, 3, pp. 39-55.

(2017), 'Afterword: Confidence in art as evidence', in M. Reason and N. Rowe (eds), Applied Practice: Evidence and Impact in Theatre, Music and Art, London: Bloomsbury Methuen Drama, pp. 262-327.

(2018), 'Introduction: Artist-educator-researcher' in R. W. Prior (ed.) (2018), Using Art As Research In Learning And Teaching: Multidisciplinary Approaches Across The Arts, Bristol: Intellect/University of Chicago Press. Rumbold, Jean, Fenner, Patricia and Brophy-Dixon, Janine (2013), 'The risks of representation: Dilemmas and opportunities in art-based research', Journal of Applied Arts and Health, 3: 1, pp. 67-78.

Sextou, Persephone (2016), Theatre For Children in Hospital: The Gift of Compassion, Bristol: Intellect.

Taylor, Philip (2003), Applied Theatre: Creating transformative encounters in the community, Portsmouth, NH: Heinemann.

Tilbrook, Ackland, Dwyer, Trudy, Reid-Searl, Kerry (2017), 'A review of the literature - The use of interactive puppet simulation in nursing education and children's healthcare', Nurse Education in Practice, 22, pp. 73-79.

Trimingham, Melissa (2010), 'Objects in transition: The puppet and the autistic child', Journal of Applied Arts and Health, 1: 3, pp. 251-265. 


\section{Contributor details:}

Professor Ross W. Prior is best known for his two books Teaching Actors: Knowledge Transfer in Actor Training and, most recently, Using Art as Research in Learning and Teaching. In 2015 he was appointed Professor of Learning and Teaching in the Arts in Higher Education at the University of Wolverhampton. He is the founding principal editor of the Journal of Applied Arts and Health, established in 2009, a member of the Arts \& Humanities Research Council (AHRC) Peer Review College, a Fellow of the Royal Society for Public Health and Principal Fellow of the Higher Education Academy.

\section{Contact:}

University of Wolverhampton, Faculty of Arts, Business and Social Sciences, The Performance Hub, Walsall Campus, Gorway Road, Walsall WS1 3BD, United Kingdom.

E-mail: r.prior@wlv.ac.uk

ORCID: 0000-0002-1521-5552 